EDUKACJA MIĘDZYKULTUROWA

2016, nr 5

ISSN 2299-4106

\title{
Gabriela PiechaczeK-Ogierman
}

\section{Szkoła w środowisku wielokulturowym i jej rola w kształtowaniu tożsamości uczniów}

Streszczenie: Szkoła na obszarze zróżnicowanym kulturowo - będąc miejscem codziennych kontaktów z Innymi, wzajemnego oddziaływania dziedzictwa kulturowego oraz uczestnictwa w życiu społecznym różnych grup - zmaga się z różnymi wyzwaniami i potrzebami, które stawiają przed nią społeczeństwo, różne systemy oświatowe i grupy narodowe. Wśród wielu zadań realizowanych przez szkołę w środowisku zróżnicowanym kulturowo szczególnego znaczenia nabierają działania związane z kształtowaniem tożsamości uczniów na wielu płaszczyznach (rodzinnej, regionalnej, narodowej, europejskiej). Celem artykułu jest ukazanie specyfiki szkolnej edukacji, uwarunkowanej zarówno doświadczeniami z historycznej przeszłości, świadomością narodową, jak również zachodzącymi procesami integracji i globalizacji. Artykuł ma charakter przeglądowy, obejmuje syntezę wybranych opracowań teoretycznych i komunikatów z badań publikowanych od ponad 25 lat w serii „Edukacja Międzykulturowa”.

Słowa kluczowe: szkoła, środowiska wielokulturowe, edukacja wielo- i międzykulturowa, tożsamość kulturowa

Szkoła - jako podstawowa instytucja edukacyjna, system kształcenia i wychowania, wspólnota - w rzeczywistości społecznej pełni wiele funkcji. Jej zadaniem jest zapewnienie uczniom warunków do wszechstronnego rozwoju, kształtowanie ich postaw, umiejętności i kompetencji, aby lepiej mogli rozumieć siebie i świat oraz umieli świadomie i aktywnie włączać się w rzeczywistość społeczną i ekonomiczną ${ }^{1}$. Zdaniem T. Lewowickiego, w dobie gwałtownego postępu cywilizacyjnego, rozwoju nowoczesnych technologii przekazu informacji konieczne wydają się przeobrażenia tradycyjnych funkcji szkoły. W nowoczesnej szkole, uwzględniającej zmiany społeczne i kulturowe, „edukacja będzie nie tyle dostarczać wiedzę, co raczej pomagać w jej

1 Por. Cz. Banach: Zadania i cechy dobrej szkoty jako organizacji uczacej się $i$ doskonalacej. W: B. Muchacka (red.): Szkoła w nauce i praktyce edukacyjnej. T. 1. Kraków 2006, Oficyna Wydawnicza „Impuls”, s.105. 
poszukiwaniu, selekcji, opracowywaniu, komentowaniu i stosowaniu. Szkoła może służyć innym niż dotąd celom. Nie tyle zdobywanie informacji, co raczej głównie uzyskiwanie porad, konsultacji (także w sprawach uczenia się treści i metod), systematyzowanie wiedzy zajmować będzie dzieci i młodzież w szkole. Pozostanie ona [...] również miejscem kontaktów społecznych, miejscem nabywania i kształtowania (się) postaw, umiejętności współpracy. W szkole będzie można uzyskać pomoc w wielu dziedzinach aktywności edukacyjnej i pozaedukacyjnej. Funkcje doradcze, środowiskowe czy kulturotwórcze mogą i powinny przywrócić tej instytucji rangę użyteczności społecznej, a edukację uwolnić od sztuczności na rzecz realizacji rzeczywistych potrzeb jednostek i grup społecznych"2. W opinii autora ważnym zadaniem szkoły jest także propagowanie wartościowych modeli życia, pozwalających na zachowanie tożsamości i podmiotowości grup i jednostek ${ }^{3}$. „W tym zakresie szkoła powinna zmienić także własne ideologie i modele działalności edukacyjnej, generować zmiany wewnętrzne (wewnątrzsystemowe) i reagować na transformacje różnych dziedzin życia pozaszkolnego"4.

W stosunku do szkoły funkcjonującej w środowisku wielokulturowym, a zwłaszcza szkoły mniejszościowej, pojawiają się szczególne oczekiwania. Szkoła - będąc miejscem codziennych kontaktów z Innymi, wzajemnego oddziaływania dziedzictwa kulturowego oraz uczestnictwa w życiu społecznym różnych grup - zmaga się z różnymi wyzwaniami i potrzebami, które stawiają przed nią różne systemy oświatowe, różnorodne społeczeństwa i grupy narodowe ${ }^{5}$. Wśród wielu zadań realizowanych przez szkołę w środowisku zróżnicowanym kulturowo szczególnego znaczenia nabierają takie działania, jak:

- rozwijanie tożsamości uczniów na wielu płaszczyznach (rodzinnej, regionalnej, narodowej, europejskiej),

- wprowadzanie w pluralizm kulturowy i wyznaniowy,

- kształtowanie podmiotowości i autonomii uczniów,

- wprowadzanie w świat wartości uniwersalnych,

- rozwijanie postaw otwartości i tolerancji,

2 T. Lewowicki: O tożsamości, kondycji i powinnościach pedagogiki. Warszawa Radom 2007, Instytut Technologii Eksploatacji - PIB, s. 137-138.

3 Tamże, s. 134.

4. Tamże.

5 Por. T. Lewowicki: Przemiany doktryny i teleologii edukacyjnej a realizowane funkcje szkoty (casus szkolnictwa na Zaolziu). W: T. Gospodarek, Z. Jasiński (red.): Edukacja w procesie przemian cywilizacyjnych i kulturowych. Opole 1993, Wyższa Szkoła Pedagogiczna im. Powstańców Śląskich. 
- wyposażenie uczniów w wiedzę o własnym regionie - historyczną, geograficzno-przyrodniczą, literacką ${ }^{6}$.

W raportach $\mathrm{z}$ badań oraz $\mathrm{w}$ pracach publikowanych $\mathrm{w}$ serii „Edukacja Międzykulturowa" wiele uwagi poświęca się szkole, jej działaniom, ukazuje inicjatywy, które w różnym stopniu sprzyjają potrzebom i dążeniom zróżnicowanego kulturowo społeczeństwa. Zmiany programowe w $1999 \mathrm{roku}^{7} \mathrm{i}$ latach następnych ${ }^{8}$ stworzyły nowe warunki szkolnych działań w zakresie edukacji wielo- i międzykulturowej. W kontekście tych zmian szkoła postrzegana jest jako instytucja: rozwijająca u uczniów poczucie przynależności do grupy rodzinnej, społeczności lokalnej, grupy etnicznej, narodu, państwa, społeczności europejskie i światowej; kształtująca postawy ciekawości, otwartości i poszanowania wobec innych kultur; służąca transmisji i pomnażaniu dziedzictwa kulturowego w regionie; kształtująca tożsamość narodową w powiązaniu z tożsamością regionalną oraz tożsamość europejską na gruncie miłości do małej i wielkiej ojczyzny; stwarzająca konkretne formy i możliwości współpracy i wymiany młodzieżowej oraz uczestnictwa w życiu publicznym zintegrowanej Europy.

Celem artykułu jest przybliżenie roli szkoły w kształtowaniu tożsamości uczniów w środowisku wielokulturowym oraz ukazanie zachodzących przemian w tym zakresie pod wpływem procesów integracji i globalizacji. Artykuł ma charakter przeglądowy, obejmuje syntezę wybranych opracowań teoretycznych i komunikatów z badań publikowanych od ponad 25 lat w serii „Edukacja Międzykulturowa”.

\section{Rozwijanie tożsamości uczniów - wybrane przykłady}

Proces tworzenia się tożsamości opiera się na wizji własnej biografii, na własnej koncepcji życia, na wiedzy o sobie, otoczeniu, świecie i postrzeganiu

6 Por. B. Grabowska: Szkoła w środowisku zróżnicowanym kulturowo. W: T. Lewowicki, A. Szczurek-Boruta (red.): Szkoła na pograniczach. Katowice 2000, UŚ, s. 70.

7 Rozporządzenie Ministra Edukacji Narodowej z dnia 15 lutego 1999 roku w sprawie podstawy programowej kształcenia ogólnego dla szkół podstawowych i gimnazjów (Dz.U. 1999, nr 14, poz. 129).

8 Rozporządzenie Ministra Edukacji Narodowej z dnia 22 lutego 2002 roku w sprawie podstawy programowej kształcenia ogólnego w poszczególnych typach szkół (Dz.U. 2002, nr 51, poz. 458); Rozporządzenie Ministra Edukacji Narodowej z 23 grudnia 2008 roku w sprawie podstawy programowej wychowania przedszkolnego oraz kształcenia ogólnego w poszczególnych typach szkół (Dz.U. z 2009 r. Nr 4, poz. 17). 
w nim własnego miejsca. Dziecko, sytuując siebie w świecie, rozpoczyna w sposób świadomy i odpowiedzialny kreować własne Ja, budować własną tożsamość jako zbiór uświadomionych autocharakterystyk (definicji siebie). Zdaniem J. Nikitorowicza o kreowaniu tożsamości, o ustawicznym procesie budowania autonomii i samoświadomości można mówić dopiero wtedy, gdy dziecko potrafi zrozumieć i ocenić samo siebie, przyjąć krytyczny stosunek do różnych sytuacji, warunków, grup i ludzi ${ }^{9}$.

Zagadnienie tożsamości używane jest nie tylko w odniesieniu do samoświadomości jednostki, a także do podkreślenia jej niepowtarzalności, własnej odrębności, spójności i ciągłości, gdyż tożsamość kształtuje się zarówno przez identyfikację z innymi (upodobnianie), jak również przez różnicowanie i znajdowanie własnej odrębności ${ }^{10}$. Ma to istotne znaczenie w sytuacji zróżnicowania kulturowego. $Z$ jednej strony człowiek ma poczucie „swojskości”, „bycia sobą”, „bycia u siebie”, z drugiej zaś - doświadcza „obcości”, „inności”, pozostając w nieustannej konfrontacji z ludźmi i grupami, ich kulturą, tradycjami, stylem życia oraz sposobem zachowań i działań ${ }^{11}$.

Człowiek kształtuje swoją tożsamość w procesie wychowania, samowychowania, uczestnictwa w życiu społecznym poprzez identyfikację i porównanie z innymi. Nabywanie określonych kompetencji kulturowych dokonuje się przede wszystkim poprzez reprodukcję kulturową w rodzinie, w społeczności lokalnej, a następnie w szkole, gdzie w sposób zorganizowany, na bazie nowych wartości, dziecko może poszerzać i nabywać nowe kompetencje, a także przekształcać już ukształtowane ${ }^{12}$.

Rolę, jaką szkoła odgrywa w kreowaniu wielowymiarowej tożsamości jednostki, nakreślą wyniki badania opublikowane w serii poświęconej wielokulturowości i edukacji międzykulturowej. Podstawę teoretyczną dla wielu badań stanowi Teoria Zachowań Tożsamościowych autorstwa Tadeusza Lewowickiego ${ }^{13}$. Badacze w swojej pracy odwołują się do wybranych obszarów,

9 Por. J. Nikitorowicz: Kreowanie tożsamości dziecka. Wyzwania edukacji międzykulturowej. Gdańsk 2005, GWP, s. 61.

10 Tamże, s. 61.

11 Tamże, s. 96-97.

12 Por. J. Nikitorowicz: Konteksty lokalno-szkolne kreowania tożsamości kulturowej w warunkach wielokulturowości. W: T. Lewowicki, A. Szczurek-Boruta, B. Grabowska (red.): Przemiany społeczno-cywilizacyjne i edukacja szkolna - problemy rozwoju indywidualnego i kształtowania się tożsamości. Cieszyn - Warszawa - Kraków 2005, Oficyna Wydawnicza „Impuls”, s. 195.

13 Por. T. Lewowicki: O badaniach społeczności pogranicza - od parcjalnych opi- 
wyznaczników poczucia tożsamości - określających i wyjaśniających zachowania tożsamościowe jednostki.

Tożsamość kulturowa kreowana jest w wyniku socjalizacji i kulturalizacji, rozumianej jako wzorce i symbole kulturowe. Rodzice oraz osoby z najbliższego otoczenia poprzez kontakty werbalne dostarczają dziecku wzorów zachowań językowych, stymulują rozwój umiejętności językowych swoich dzieci. W rejonach o silnym poczuciu więzi etnokulturowej (na Śląsku, Kaszubach, Podhalu) większość dzieci z rodzin autochtonicznych przyswaja we wczesnym dzieciństwie rodzimą gwarę. W rodzinach dzieci zaolziańskich używa się gwary ${ }^{14}$, natomiast językiem codziennych kontaktów z rówieśnikami i sąsiadami jest język czeski. Dopiero w szkole następuje przyswajanie polszczyzny ogólnej w formie dydaktyczno-normatywnej (nakazy i polecenia), potocznej (rozmowy wychowawcy z dziećmi) oraz artystycznej (odbiór tekstów literackich, lektur, recytacje, inscenizacje). Na Zaolziu szkoły z polskim językiem nauczania nastawione są przede wszystkim na kształtowanie poczucia tożsamości narodowej ${ }^{15}$. Program kształcenia języka ogólnonarodowego w szkołach zaolziańskich sprzyja kształtowaniu zainteresowania uczniów językiem i literaturą polską, zarówno w toku zajęć lekcyjnych, jak i pozalekcyjnych (zajęcia fakultatywne, konkursy i olimpiady języka polskiego, kółka miłośników gwary, kluby korespondentów, „kąciki językowe" w prasie zaolziańskiej). Szkoła w środowisku zaolziańskim jest najważniejszym czynnikiem kształtującym polszczyznę ogólną, która jest głównym nośnikiem kultury i edukacji narodowej.

sów ku elementom teorii zachowań tożsamościowych. W: J. Nikitorowicz (red.): Edukacja międzykulturowa: w kręgu potrzeb, oczekiwań i stereotypów. Białystok 1995, Wydawnictwo Uniwersyteckie „Trans Humana”, s. 13-27; T. Lewowicki: Problemy tożsamości narodowej - w poszukiwaniu sposobów uogólnionych ujęć kwestii poczucia tożsamości i zachowań z tym poczuciem zwiazanych. W: M. M. Urlińska (red.): Edukacja a tożsamość etniczna. Toruń 1995, UMK, s. 51-63.

14 Polskość Zaolzia przejawia się nie tyle w systematycznym posługiwaniu się językiem polskim, a raczej jego regionalną odmianą - gwarą zachodniocieszyńską. Uczeń zaolziański niemal we wszystkich sytuacjach pozalekcyjnych mówi gwarą, polszczyzny ogólnej w mowie i piśmie używa tylko na lekcjach języka polskiego i innych przedmiotach.

15 Por. A. Szczypka-Rusz: Język i kultura - istotne składniki tożsamości kulturowej mtodzieży pogranicza. W: T. Lewowicki (red.): Poczucie tożsamości narodowej mtodzieży - studium z pogranicza polsko-czeskiego. Cieszyn 1994, UŚ - Filia w Cieszynie, s. 29-40; A. Szczypka-Rusz: Kwestia wielokulturowości w dziatalności szkoty z polskim językiem nauczania w Czechach (szkic problemu). W: T. Lewowicki, A. Szczurek-Boruta (red.): Szkoła na pograniczach. Katowice 2000, UŚ, s. 84. 
Wiele uwagi językowi uczniów w szkole w środowisku wielokulturowym w swojej działalności badawczej poświęciły współpracujące ze Społecznym Zespołem Badań Kultury i Oświaty Pogranicza - Z. Matyska i H. Synowiec ${ }^{16}$. Ich prace pozwalają lepiej zrozumieć zachowania językowe uczniów, które wynikają z odrębności kulturowej środowiska regionalnego. Autorki opisują także działania dydaktyczne uwzględniające potrzeby uczniów ze środowisk gwarowych. Mimo że specyfika językowo-kulturowa poszczególnych regionów nie znajduje bezpośrednio odzwierciedlenia w programach nauczania (za wyjątkiem Kaszub) ${ }^{17}$, to jednak zgromadzone dane wskazują konkretne działania podejmowane w szkole, które przyczyniają się do kształtowania tożsamości regionalnej uczniów. Celem działań nauczycieli nie jest jednak zwalczanie gwary w szkole, ale pokazanie jej znaczenia i roli w kształtowaniu tożsamości regionalnej uczniów. W szkole organizowane są konkursy recytacji w gwarze, spotkania z gawędziarzami ludowymi, przeglądy piosenki dziecięcej („śląskie śpiewanie”) ${ }^{18}$ oraz eksperymenty pedagogiczne promujące muzyczne wartości regionalne ${ }^{19}$.

Odmienną sytuację możemy zaobserwować wśród mniejszości polskiej na Białorusi, gdzie w wyniku silnej indoktrynacji ze strony systemu sowieckiego w wielu przypadkach doszło do wykorzenienia kulturowego. Dla młodych Białorusinów identyfikujących się z polskością to właśnie szkoła z polskim językiem nauczania jest jedynym miejscem kontaktu z polskim dziedzictwem

16 Por. Z. Matyska: Rozwijanie sprawności i świadomości językowej dzieci w wielojęzycznym środowisku Zaolzia. W: T. Lewowicki, A. Szczurek-Boruta (red.): Szkoła na pograniczach. cyt. wyd., s. 61-68; H. Synowiec: Zróżnicowanie regionalne języka uczniów a dydaktyka szkolna. W: T. Lewowicki, A. Szczurek-Boruta (red.): Szkoła na pograniczach. cyt. wyd., s. 119-126.

17 Por. K. Kossak-Główczewski: Edukacja regionalna a regionalizacja nauczania jako odmiany racjonalności (pytanie o szansę dekolonizacji przez edukację). W: T. Lewowicki, B. Grabowska (red.): Społeczności pogranicza. Wielokulturowość. Edukacja. Cieszyn - Warszawa 1996, UŚ - Filia w Cieszynie, Wyższa Szkoła Pedagogiczna ZNP w Warszawie; R. Mistarz: Kaszubska edukacja $w$ teorii i praktyce. W: T. Lewowicki, E. Ogrodzka-Mazur (red.): Z teorii i praktyki edukacji międzykulturowej. Cieszyn Warszawa 2006, UŚ, Wyższa Szkoła Pedagogiczna ZNP w Warszawie.

18 Por. H. Synowiec: Zróżnicowanie regionalne języka uczniów a dydaktyka szkolna. W: T. Lewowicki, A. Szczurek-Boruta (red.): Szkoła na pograniczach. cyt. wyd., s. 122.

19 Por. J. Uchyła-Zroski: Znaczenie edukacyjnych wartości muzyki w procesie przekazywania tradycji. W: T. Lewowicki, A. Szczurek-Boruta (red.): Szkoła na pograniczach. cyt. wyd., s. 137-147. 
kulturowym ${ }^{20}$. Potwierdzają to przytaczane przez M. Sobeckiego egzemplifikacje poczucia tożsamości młodych ludzi, którzy nie mając kontaktu z językiem dziadków, na nowo - dzięki szkole - odczytują swoją tożsamośćn ${ }^{21}$. Język polski jako priorytetowy czynnik w tworzeniu polskiej tożsamości ma także wymiar pragmatyczny. Młodzi ludzie traktują szkołę z językiem polskim jako narzędzie umożliwiające studiowanie w Polsce, warunkujące życie na wyższym poziomie ${ }^{22}$.

Badania prowadzone na Zaolziu przez E. Ogrodzką-Mazur i A. Szafrańską-Gajdzicęę i E. Ogrodzką-Mazur w 2008 roku pozwoliły również uchwycić nowe zjawisko wśród dorastającej młodzieży, pośrednio związane kreowaniem ich tożsamości ${ }^{23}$. Uczniowie z jednej strony odczuwają dumę z powodu chodzenia do szkoły z polskim językiem nauczania, a z drugiej kompleksy. Szkoły mniejszościowe nie zawsze spełniają oczekiwania uczniów i ich rodziców, zwłaszcza pod względem przygotowania do przyszłego zawodu, udanej kariery edukacyjnej na czeskich uczelniach. W ostatnich latach młodzież deklaruje wyższy poziom aspiracji edukacyjnych niż na początku lat 90. ${ }^{24}$ Młodzi ludzie chętnie uczą się języków obcych, dzięki kompetencjom językowym czują się mieszkańcami Europy, a nawet świata ${ }^{25}$.

20 Aktualnie na Białorusi funkcjonują dwie szkoły z polskim językiem nauczania (średnie szkoły w Grodnie i Wołkowysku), które prowadzą szeroko zakrojoną działalność związaną z nauczaniem języka polskiego oraz kultywowaniem dziedzictwa narodowego, z uwzględnieniem idei edukacji międzykulturowej.

21 Por. M. Sobecki M: Poczucie tożsamości narodowej absolwentów szkót z polskim językiem nauczania na Biatorusi. W: T. Lewowicki, E. Ogrodzka-Mazur (red.): Polityka spoteczna $i$ oświatowa a edukacja międzykulturowa. Cieszyn - Warszawa 2005, Wyższa Szkoła Pedagogiczna ZNP w Warszawie, UŚ - Filia w Cieszynie, s. 240-248.

22 Tamże, s. 248.

23 Por. A. Gajdzica, E. Ogrodzka-Mazur: Obraz szkoty na pograniczu w kontekście oczekiwań edukacyjnych uczniów. W: T. Lewowicki, E. Ogrodzka-Mazur, A. Szczurek-Boruta (red.): Poczucie tożsamości i stosunek mtodzieży do wybranych kwestii społecznych - studium z pogranicza polsko-czeskiego. cyt. wyd., s. 169-189.

24 Por. A. Gajdzica, E. Ogrodzka-Mazur: Szkoła na pograniczu jako środowisko ksztattowania aspiracji i planów edukacyjnych młodzieży. W: T. Lewowicki, E. Ogrodzka-Mazur, A. Szczurek-Boruta (red.): Poczucie tożsamości i stosunek młodzieży do wybranych kwestii społecznych - studium z pogranicza polsko-czeskiego. cyt. wyd., s. 190-225.

25 Porównanie wyników badań z początku lat 1990-1994 B. Grabowskiej i A. Szczurek-Boruty z lat 2000-2004. B. Grabowska: Identyfikacja z grupa społeczna jako czynnik tożsamości narodowej. W: T. Lewowicki (red.): Poczucie tożsamości narodowej młodzieży. 
Znajomość losów historycznych swojego regionu, narodu, faktów z przeszłości, wybitnych postaci konstytuuje zachowania tożsamościowe jednostki. W kontekście poznawczym wiedza o dziedzictwie kulturowym zwiększa świadomość jednostki, ułatwiając rozumienie siebie i własnej tożsamości.

Wyniki badań prowadzonych w latach 30. minionego wieku wykazały, że poziom wiedzy historycznej przekazywanej na lekcjach historii oraz w ramach innych przedmiotów - języka polskiego, wiedzy o społeczeństwie, geografii - jest bardzo niski ${ }^{26}$. Niezintegrowana i fragmentaryczna wiedza historyczna okazała się niezrozumiała i nietrwała nie tylko dla uczniów szkół zaolziańskich realizujących czeski program nauczania, ale również dla uczniów w Polsce. Także badania prowadzone w 2005 roku pozwoliły stwierdzić, że znajomość historii wśród badanych uczniów jest powierzchowna i ogranicza się do kilku symbolicznych faktów ${ }^{27}$. Treści szkolnej edukacji historycznej, nastawione na realizację tematów związanych z dziejami kraju i świata, pomijają dzieje regionu - Małej Ojczyzny.

Oprócz powyższych przykładów w publikacjach z serii edukacji wieloi międzykulturowej możemy odnaleźć jednostkowe egzemplifikacje interesujących działań szkoły w rozwijaniu poczucia więzi z regionalną ojczyzną prywatną. Środowisko szkolne w wielu przypadkach okazało się otwarte na propozycje współpracy ze strony instytucji lokalnych czy środowisk akademickich. W roku 1996 kilkadziesiąt szkół województwa Śląskiego wzięło udział w konkursie na program edukacji regionalnej zorganizowanym z inicjatywy Kuratorium Oświaty w Katowicach i Sejmiku Samorządowego Województwa Katowickiego. Większość tych projektów konkursowych była realizowana w szkołach jako innowacja pedagogiczna lub w ramach zajęć pozalekcyjnych ${ }^{28}$.

Studium z pogranicza polsko-czeskiego. cyt. wyd., s. 45; Por. A. Szczurek-Boruta: Edukacja i odkrywanie tożsamości w warunkach wielokulturowości. Szkice pedagogiczne. Katowice - Cieszyn - Kraków 2007, Oficyna Wydawnicza „Impuls”, s. 76-78.

26 Por. J. Suchodolska: Próba określenia świadomości narodowej młodzieży narodowości polskiej i narodowości czeskiej - na tle wiedzy historycznej badanych grup uczniów. W: T. Lewowicki (red.): Poczucie tożsamości narodowej mtodzieży. cyt. wyd., s. $15-28$.

27 Por. G. Piechaczek-Ogierman, I. Krzemińska-Woźniak: Poczucie tożsamości kulturowej uczniów a edukacja międzykulturowa. W: T. Lewowicki E. Ogrodzka-Mazur (red.): Z teorii i praktyki edukacji międzykulturowej. cyt. wyd., s. 200-202.

28 Por. B. Sopot-Zembok, H. Nocoń: Aktualne problemy edukacji regionalnej. W: T. Lewowicki, A. Szczurek-Boruta (red.): Szkoła na pograniczach. cyt. wyd., s. 130-131 . 
Innym przykładem jest czteroletni eksperyment pedagogiczny Dziedzictwo kulturowe regionu pszczyńskiego realizowany z inicjatywy i pod kierunkiem nauczycieli akademickich ${ }^{29}$. W eksperymencie zastosowano twórczą metodę poliestetyczną polegającą na naprowadzaniu ucznia do samodzielnego poszukiwania i rozwiązania. Bodźcem do działań odtwórczo-twórczych była wiedza o regionie - historyczna, antropologiczna, socjokulturowa, a także sztuka plastyczna, treści muzyczne i literackie. $Z$ inicjatywy środowiska naukowego realizowany był również kilkuletni cykl zajęć z zakresu edukacji wielo- i międzykulturowej. Studenci w ramach ćwiczeń - aksjologiczne podstawy edukacji wielo- i międzykulturowej - wdrażali swoje autorskie projekty ${ }^{30}$.

W ostatnich latach coraz więcej szkół włącza się do współpracy z instytucjami oświatowymi ${ }^{31}$, które rozumiejąc wartość i ważność edukacji międzykulturowej i regionalnej, opracowują projekty edukacyjne (Kolorowe Ścieżki Euroregionu, Lekcja regionalizmu na żywo) służące integracji społecznej i kulturowej mieszkańców, przełamywaniu stereotypów, rozwijaniu odpowiedzialności za dziedzictwo kulturowe; pogłębieniu emocjonalnego stosunku do tradycji i kultury najbliższego regionu. Inicjatorzy tych projektów umożliwiają, zarówno nauczycielom, jak i uczniom, uczestniczenie w warsztatach międzykulturowych, udostępniając materiały szkoleniowe w postaci publikacji książkowych.

29 Por. J. Uchyła-Zroski: Znaczenie edukacyjnych wartości muzyki w procesie przekazywania tradycji. W: T. Lewowicki, A. Szczurek-Boruta (red.): Szkoła na pograniczach. cyt. wyd., s. 137-147.

30 Tematyka wykładów i ćwiczeń została opracowana przez prof. UŚ dr hab. Ewę Ogrodzką-Mazur. Por. G. Piechaczek-Ogierman, I. Krzemińska-Woźniak: Poczucie tożsamości kulturowej uczniów a edukacja międzykulturowa. W: T. Lewowicki E. Ogrodzka-Mazur (red.): Z teorii i praktyki edukacji międzykulturowej. cyt. wyd., s. 197-214.

31 Przykładem są działające na pograniczu polsko-czeskim Centrum Pedagogiczne dla Szkolnictwa Narodowościowego w Czeskim Cieszynie oraz Żorskie Centrum Regionalizmu. Ich działalność opisują: A. Gajdzica, B. Kubiczek: Wspieranie nauczycieli w środowisku mniejszościowym na przykładzie działalności Centrum Pedagogicznego dla Szkolnictwa Narodowościowego w Czeskim Cieszynie. W: T. Lewowicki, A. Różańska, G. Piechaczek-Ogierman (red.): Wielokulturowość i problemy edukacji. Cieszyn - Warszawa - Toruń 2012, Wydział Etnologii i Nauk o Edukacji Uniwersytetu Śląskiego, Wyższa Szkoła Pedagogiczna ZNP w Warszawie, Stowarzyszenie Wspierania Edukacji Międzykulturowej, Wydawnictwo Adam Marszałek; G. Piechaczek -Ogierman: Lekcja regionalizmu na żywo - propozycja dla szkolnej edukacji. „Ruch Pedagogiczny" 2012, nr 4. 


\section{Podsumowanie}

Reforma oświaty stworzyła podstawy prawne do podejmowania działań pedagogicznych umożliwiających uczniom pełniejsze poznanie dziedzictwa kulturowego. Założenia programowe mogą być wykorzystane w każdym regionie, środowisku i miejscowości, gdyż podstawa programowa w sposób ogólny wskazuje problematykę, zakres treści i określa cele. Szkolny program nauczania łączy treści z zakresu dziedzictwa kulturowego i historii z ideami wielokulturowości. Jednakże jego realizacja, jak wykazały przytoczone przykłady, różni się w poszczególnych placówkach szkolnych.

Na obszarze zróżnicowanym kulturowo funkcjonują szkoły, które w szczególny sposób stwarzają warunki do wzbogacania tożsamości uczniów w wymiarze - europejskim, narodowym, regionalnym, lokalnym. Nauczyciele w toku lekcji wykorzystują okazje do rozmów o zwyczajach, tradycjach rodzinnych uczniów. W ten sposób urzeczywistnia się nie tylko dialog międzygeneracyjny, ale także pomiędzy społecznością autochtoniczną a mieszkańcami mniejszościowymi i napływowymi. Elementy szeroko pojętej edukacji międzykulturowej, ujęte w podstawie programowej, mają również swoje odzwierciedlenie w ofercie programów i podręczników dla klas I-III. Zgodnie z koncepcją kształcenia zintegrowanego, edukacja uczniów w klasach początkowych przebiega zgodnie z zasadą: od rzeczy bliskich do dalekich, od znanych do nieznanych. W analizowanych podręcznikach tematy skupione na kulturze rodzinnej i lokalnej umożliwiają uczniom zauważyć innych i poznać ich kultury ${ }^{32}$. Edukacja wywodząca się od Małej Ojczyzny jest dla dziecka naturalną drogą kształtowania poczucia tożsamości regionalnej, narodowej, europejskiej.

Działania edukacyjne szkół oraz ich współpraca z środowiskiem lokalnym, uwarunkowane historycznie, w dużej mierze zależą od zasobów społeczno-kulturowych danej społeczności. Przytoczeni w artykule autorzy niejednokrotnie zwracają uwagę na fakt, że wdrażanie treści z zakresu edukacji międzykulturowej i regionalnej w środowisku wielokulturowym (przez nauczycieli o różnie ukształtowanej tożsamości) wymaga systematycznego

32 Por. A. Gajdzica: Możliwości kształtowania tożsamości dzieci młodszych na podstawie analizy wybranych programów dla klas I-III. W: T. Lewowicki, A. Szczurek -Boruta, B. Grabowska (red.): Społeczne uwarunkowania edukacji międzykulturowej. Problemy praktyki oświatowej. cyt. wyd., s. 93-103. 
wsparcia nie tylko metodycznego, ale przede wszystkim merytorycznego. W badanym w środowisku istnieją także placówki mało dynamiczne, w których podejmowane działania sprzyjają zachowaniom adaptacyjnym, zamykaniu uczniów we własnym kręgu kulturowym.

\section{Bibliografia}

Banach Cz.: Zadania i cechy dobrej szkoty jako organizacji uczacej się $i$ doskonalacej. W: B. Muchacka (red.): Szkoła w nauce i praktyce edukacyjnej. T. 1. Kraków 2006, Oficyna Wydawnicza „Impuls”

Gajdzica A.: Możliwości kształtowania tożsamości dzieci młodszych na podstawie analizy wybranych programów dla klas I-III. W: T. Lewowicki, A. Szczurek-Boruta, B. Grabowska (red.): Społeczne uwarunkowania edukacji międzykulturowej. Problemy praktyki oświatowej. Cieszyn - Warszawa - Toruń 2009, Wydział Etnologii i Nauk o Edukacji Uniwersytetu Śląskiego, Wyższa Szkoła Pedagogiczna ZNP w Warszawie, Wydawnictwo Adam Marszałek.

Gajdzica, B. Kubiczek: Wspieranie nauczycieli w środowisku mniejszościowym na przykładzie działalności Centrum Pedagogicznego dla Szkolnictwa Narodowościowego w Czeskim Cieszynie. W: T. Lewowicki, A. Różańska, G. Piechaczek-Ogierman (red.): Wielokulturowość i problemy edukacji. Cieszyn - Warszawa - Toruń 2012, Wydział Etnologii i Nauk o Edukacji Uniwersytetu Śląskiego, Wyższa Szkoła Pedagogiczna ZNP w Warszawie, Stowarzyszenie Wspierania Edukacji Międzykulturowej, Wydawnictwo Adam Marszałek.

Gajdzica A., Ogrodzka-Mazur E.: Obraz szkoty na Pograniczu w kontekście oczekiwań edukacyjnych uczniów. W: T. Lewowicki, E. Ogrodzka-Mazur, A. Szczurek-Boruta (red): Poczucie tożsamości i stosunek młodzieży do wybranych kwestii społecznych - studium z pogranicza polsko-czeskiego. Cieszyn - Warszawa - Toruń 2009, Wydział Etnologii i Nauk o Edukacji Uniwersytetu Śląskiego, Wyższa Szkoła Pedagogiczna ZNP w Warszawie, Wydawnictwo Adam Marszałek.

Gajdzica A., Ogrodzka-Mazur E.: Szkoła na pograniczu jako środowisko kształtowania aspiracji i planów edukacyjnych młodzieży. W: T. Lewowicki, E. Ogrodzka-Mazur, A. Szczurek-Boruta (red.): Poczucie tożsamości i stosunek mtodzieży do wybranych kwestii społecznych - studium z pogranicza polsko-czeskiego. Cieszyn - Warszawa - Toruń 2009, Wydział 
Etnologii i Nauk o Edukacji Uniwersytetu Śląskiego, Wyższa Szkoła Pedagogiczna ZNP w Warszawie, Wydawnictwo Adam Marszałek.

Grabowska B.: Identyfikacja z grupq spoteczna jako czynnik tożsamości narodowej. W: T. Lewowicki (red.): Poczucie tożsamości narodowej młodzieży. Studium z pogranicza polsko-czeskiego. Cieszyn 1994, UŚ - Filia w Cieszynie.

Grabowska B.: Szkoła w środowisku zróżnicowanym kulturowo. W: T. Lewowicki, A. Szczurek-Boruta (red.): Szkoła na pograniczach. Katowice 2000, UŚ.

Kossak-Główczewski K.: Edukacja regionalna a regionalizacja nauczania jako odmiany racjonalności (pytanie o szansę dekolonizacji przez edukację). W: T. Lewowicki, B. Grabowska (red.): Społeczności pogranicza. Wielokulturowość. Edukacja. Cieszyn - Warszawa 1996, UŚ - Filia w Cieszynie, Wyższa Szkoła Pedagogiczna ZNP w Warszawie.

Lewowicki T.: Przemiany doktryny i teleologii edukacyjnej a realizowane funkcje szkoty (casus szkolnictwa na Zaolziu). W: T. Gospodarek, Z. Jasiński (red.): Edukacja w procesie przemian cywilizacyjnych $i$ kulturowych. Opole 1993, Wyższa Szkoła Pedagogiczna im. Powstańców Śląskich.

Lewowicki T.: O badaniach społeczności pogranicza - od parcjalnych opisów ku elementom teorii zachowań tożsamościowych. W: J. Nikitorowicz (red.): Edukacja międzykulturowa: w kręgu potrzeb, oczekiwań i stereotypów. Białystok 1995, Wydawnictwo Uniwersyteckie „Trans Humana”.

Lewowicki T.: Problemy tożsamości narodowej - w poszukiwaniu sposobów uogólnionych ujęć kwestii poczucia tożsamości i zachowań z tym poczuciem zwiazanych. W: M. M. Urlińska (red.): Edukacja a tożsamość etniczna. Toruń 1995, UMK.

Lewowicki T.: O tożsamości, kondycji i powinnościach pedagogiki. Warszawa - Radom 2007, Instytut Technologii Eksploatacji - PIB.

Matyska Z.: Rozwijanie sprawności i świadomości językowej dzieci w wielojęzycznym środowisku Zaolzia. W: T. Lewowicki, A. Szczurek-Boruta (red.): Szkoła na pograniczach. Katowice 2000, UŚ.

Mistarz R.: Kaszubska edukacja w teorii i praktyce. W: T. Lewowicki, E. Ogrodzka-Mazur (red.): Z teorii i praktyki edukacji międzykulturowej. Cieszyn - Warszawa 2006, UŚ, Wyższa Szkoła Pedagogiczna ZNP w Warszawie.

Nikitorowicz J.: Konteksty lokalno-szkolne kreowania tożsamości kulturowej w warunkach wielokulturowości. W: T. Lewowicki, A. Szczurek-Boruta, B. Grabowska (red.): Przemiany społeczno-cywilizacyjne i edukacja szkol- 
na - problemy rozwoju indywidualnego i kształtowania się tożsamości. Cieszyn - Warszawa - Kraków 2005, Oficyna Wydawnicza „Impuls”. Nikitorowicz J.: Kreowanie tożsamości dziecka. Wyzwania edukacji międzykulturowej. Gdańsk 2005, GWP.

Piechaczek-Ogierman G., Krzemińska -Woźniak I.: Poczucie tożsamości kulturowej uczniów a edukacja międzykulturowa. W: T. Lewowicki E. Ogrodzka-Mazur (red.): Z teorii i praktyki edukacji międzykulturowej. Cieszyn - Warszawa 2006, UŚ, Wyższa Szkoła Pedagogiczna ZNP w Warszawie.

Piechaczek-Ogierman G., Krzemińska-Woźniak I.: Przemiany planów życiowych młodzieży zwiazanych $z$ praca $w$ innych krajach. W: T. Lewowicki, E. Ogrodzka-Mazur, A. Szczurek-Boruta (red.): Poczucie tożsamości i stosunek młodzieży do wybranych kwestii społecznych - studium z pogranicza polsko-czeskiego. Cieszyn - Warszawa - Toruń 2009, Wydział Etnologii i Nauk o Edukacji Uniwersytetu Śląskiego, Wyższa Szkoła Pedagogiczna ZNP w Warszawie, Wydawnictwo Adam Marszałek.

Sobecki M.: Poczucie tożsamości narodowej absolwentów szkót z polskim językiem nauczania na Białorusi. W: T. Lewowicki, E. Ogrodzka-Mazur (red.): Polityka spoteczna i oświatowa a edukacja międzykulturowa. Cieszyn - Warszawa 2005, UŚ - Filia w Cieszynie, Wyższa Szkoła Pedagogiczna ZNP w Warszawie.

Sopot-Zembok B., Nocoń H.: Aktualne problemy edukacji regionalnej. W: T. Lewowicki, A. Szczurek-Boruta (red.): Szkoła na pograniczach. Katowice 2000, UŚ.

Suchodolska J.: Próba określenia świadomości narodowej młodzieży narodowości polskiej i narodowość czeskiej - na tle wiedzy historycznej badanych grup uczniów. W: T. Lewowicki (red.): Poczucie tożsamości narodowej młodzieży. Cieszyn 1994, UŚ - Filia w Cieszynie.

Synowiec H.: Zróżnicowanie regionalne języka uczniów a dydaktyka szkolna. W: T. Lewowicki, A. Szczurek-Boruta (red.): Szkoła na pograniczach. Katowice 2000, UŚ.

Szczurek-Boruta A.: Edukacja i odkrywanie tożsamości w warunkach wielokulturowości. Szkice pedagogiczne. Katowice - Cieszyn - Kraków 2007, Oficyna Wydawnicza „Impuls”.

Szczypka-Rusz A.: Język i kultura - istotne sktadniki tożsamości kulturowej młodzieży pogranicza. W: T. Lewowicki (red.): Poczucie tożsamości narodowej młodzieży - studium z pogranicza polsko-czeskiego. Cieszyn 1994, UŚ - Filia w Cieszynie. 
Szczypka-Rusz A.: Kwestia wielokulturowości w dziatalności szkoty z polskim językiem nauczania w Czechach (szkic problemu). W: T. Lewowicki, A. Szczurek-Boruta (red.): Szkoła na pograniczach. Katowice 2000, UŚ. Uchyła-Zroski J.: Znaczenie edukacyjnych wartości muzyki w procesie przekazywania tradycji. W: T. Lewowicki, A. Szczurek-Boruta (red.): Szkoła na pograniczach. Katowice 2000, UŚ.

\section{School in the multicultural environment and its significance for shaping learners' identity}

\section{Summary}

As a place of daily contacts with the Other, of mutual influence of cultural heritage and participation in social life of various groups, school in culturally diversified territories handles various challenges and needs, imposed by the society, different educational systems and national groups. Among many tasks fulfilled by school in the culturally diverse environment, special significance is attributed to activities associated with shaping learners' identity in many dimensions (the family, regional, national, European one). The article is aimed at showing the specificity of school education, determined not only by the experiences of the historical past, national awareness, but also by the processes of integration and globalization. The study has a form of a review, it comprises a synthesis of some selected theoretical works and research reports published over 25 years in the series "Edukacja Międzykulturowa /Intercultural Education/".

Key words: school, multicultural environments, multi- and intercultural education, cultural identity 